\title{
A CONTROVÉRSIA DA ESTABILIZAÇÃO DA TUTELA ANTECIPADA EM CARÁTER ANTECEDENTE
}

\section{THE CONTROVERSY OF STABILIZATION OF ADVANCED PROTECTION IN ANTECEDENT QUALITY}

\author{
${ }^{1}$ Gilberto Ferreira Marchetti Filho \\ ${ }^{2}$ Jenifer Bacon Assumpção
}

\section{RESUMO}

A antecipação de tutela trata da imediata concessão dos efeitos executivos latu senso do provimento final. Segundo o CPC vigente, em casos de urgência, o pedido inicial de tutela antecipada poderá ser superficial, versando apenas sobre a situação de urgência, sem debater toda a matéria controvertida. Posteriormente, a petição inicial poderá ser aditada, para completar toda a matéria a ser discutida. Caso o réu não demonstre seu inconformismo no referente ao deferimento, seus efeitos serão estabilizados. Passado o prazo, ela se torna definitiva. Várias são as problemáticas suscitadas dessa novidade jurídica, a serem o objeto da presente reflexão.

PALAVRAS-ChAVE: Código de Processo Civil; tutela de urgência; tutela antecipada de caráter antecedente

\begin{abstract}
The preliminary injunction deals with the immediate concession of the executive effects of the final provision. According to the current CPC, in cases of urgency, the initial request for previous protection may be superficial, dealing only with the situation of urgency, without discussing all the matters at issue. Subsequently, the initial petition may be added, to complete all the matter to be discussed. If the defendant does not demonstrate his nonconformity regarding the approval, its effects will be stabilized. After the deadline, it becomes final. There are several problems arising from this legal novelty, which are the object of the present.
\end{abstract}

KEYWORDS: Civil Procedure Code; guardianship of urgency; advanced protection in antecedent quality.

\footnotetext{
${ }^{1}$ Mestrando em Processo Civil e Cidadania pela Universidade Paranaense - UNIPAR, Paraná, PR, (Brasil). Assessor Jurídico do TJMS. Professor de Direito Civil na UNIGRAN - Mato Grande do Sul, MS, (Brasil). Bolsista da Capes/Prosup. Email: gilbertomarchetti@gmail.com.

${ }^{2}$ Mestranda em Processo Civil e Cidadania pela Universidade Paranaense - UNIPAR, Paraná, PR, (Brasil).. Advogada. Email: jeniferbaccan@ hotmail.com.
} 


\section{INTRODUÇÃO}

A ciência processual deve garantir que o processo seja meio apto a realizar direitos de forma útil e efetiva, principalmente em peculiares circunstâncias urgentes, em que o não pronunciamento judicial comumente resultaria numa situação de injustiça.

Trata-se de circunstâncias especiais, em que a celeridade assume papel de destaque. Seguindo essa tônica, um dos propósitos do ante-projeto do Novo Código de Processo Civil consubstanciou-se em reforma legislativa no tocante às tutelas de urgência.

Assim, o resultado foi o Código de Processo Civil de 2015, que criou o instituto da tutela antecipada em caráter antecedente, que deve versar somente a respeito da urgência, relegando a um segundo momento a inteireza da controvérsia em questão, quando o autor teria a possibilidade de aditar o pedido inicial, desta vez com todos os pontos a serem analisados e, com isso, dotando a exordial da robustez argumentativa a ela inerente.

Desta forma, com o novo diploma processual, num primeiro momento, a análise seria sumária e, com base nela, seria possível conferir provimento ao pedido, ou antecipar a tutela. Contudo, o direito de ter sobre seu pedido, uma análise de cognição exauriente não seria suprimido, vez que, após o aditamento da inicial, o processo tomaria seu curso normal.

Não obstante, a nova lei foi além, trouxe ainda a possibilidade de, considerada a inércia do réu diante da antecipação do pedido, estabilizar os efeitos do pedido antecipado. Ou seja, pela Processual Civil, o autor pode (i) indicar apenas o pedido urgente; (ii) ver deferida a antecipação do pedido; e ainda, (iii) ter estabilizados os efeitos dessa antecipação.

Dessa significativa novidade processual, faz surgir a problematização do tema proposto. De efeito, vários questionamentos podem (e devem) surgir, a respeito dessa inércia e da estabilização dos efeitos, bem como a possibilidade de formação de uma nova espécie de coisa julgada.

Portanto, o estudo tem por objetivo analisar o novo instituto da tutela antecipada requerida em caráter antecedente presente no Código de Processo Civil de 2015, bem como as consequências da estabilização de seus efeitos.

Propõe-se aqui, formular uma despretensiosa base jurídica a fim de iniciar a discussão suscitada, e, em sede de conclusão, sugerir algumas ponderações necessárias, com a viva consciência de que somente o devido aprofundamento dogmático aliado à reiterada prática forense serão capazes de determinar a melhor solução à matéria. 
Para tanto, observando metódica dedutiva, sistêmica e axiológica, são pontuados o plano da eficácia da tutela jurisdicional e das várias formas de tutelas de urgência, demonstrando a diferenciação entre satisfatividade e definitividade, para então compreender o instituto da tutela antecipada, na atual formatação do Código de Processo Civil.

Firmado esses parâmetros iniciais, adentra-se especificamente no tema para estabelecer uma análise do instituto da tutela antecipada em caráter antecedente e a estabilização de seus efeitos.

\section{A EFETIVIDADE DA TUTELA JURISDICIONAL}

Para que o debate sobre a celeuma seja galgado em proposições cediças, unívocas, de feição científica, torna-se imprescindível lançar-se mão de estudos relativos à essência de cada tema jurídico envolvido na questão, como efetividade, celeridade, definitividade, cognição, e a origem das próprias alterações legislativas referentes à antecipação de tutela.

Em relação à efetiva prestação da tutela jurisdicional, sabe-se que se trata de função essencial à administração da justiça, para o fim de apreciar as pretensões que lhe são submetidas e, como resultado, prover a realização do direito material nela reconhecido. Segundo Fritz Baur, "somente procedimentos céleres preenchem a finalidade do processo, dando-lhe efetividade"3.

\footnotetext{
Essa coincidência traz à atividade estatal e aos litigantes o perigo da tutela tardia, o perigo da demora da resposta judicial e sua conseqüente ineficácia prática e absoluta inutilidade para o jurisdicionado. Põem-se em risco a efetividade e seriedade da atividade jurisdicional e, por conseqüência, os direitos dos litigantes. Foi justamente para garantir a qualidade da atividade judicial e manter a legitimidade do Poder Judiciário que o legislador precisou elaborar, estruturar e disponibilizar meios de assegurar a efetividade da prestação jurisdicional, sempre que verificada alguma situação que a ameace. ${ }^{4}$
}

A ciência processual abandonou a ideia de que a simples prestação jurisdicional consubstanciada numa sentença de mérito, seria suficiente a caracterizar a outorga da tutela almejada pela parte, "passando a agregar a esse conceito as noções de utilidade e efetividade

\footnotetext{
${ }^{3}$ BAUR, Fritz. Tutela jurídica mediante medidas cautelares. São Paulo: Fabris, 1985. p. 65.

${ }^{4}$ SPADONI, Joaquim Felipe. Fungibilidade das tutelas de urgência. Revista de processo. n. 110. São Paulo: Revista dos Tribunais, 2003. v. 28. p. 74.
} 
como elementos dessa tutela"5. Caso a realização do direito em questão seja tardia, a efetividade da tutela jurisdicional seria comprometida e o fim de sua prestação não alcançado.

Nesse sentido, ensina Ernane Fidelis dos Santos que:

Se o direito existe para garantir o gozo de um bem da vida, o tempo poderá frustrar-lhe a própria existência, quando, em virtude dele, não poder ser exercido a contento. Quando o direito é molestado, ameaçado ou contestado, com a proibição da justiça privada, o pretendente deve buscar do Estado a respectiva tutela jurisdicional. ${ }^{6}$

Trilhando nesse caminho, segundo Nelson Luiz Pinto, a prestação jurisdicional deve consubstanciar-se, dentre outros fatores, num "pronunciamento judicial emanado da autoridade competente dado a favor de quem esteja amparado no plano do direito material, de modo a ser útil e efetivo, assegurando-lhe a existência e o exercício"7. Para José Carlos Barbosa Moreira, "será efetivo o processo que constitua instrumento eficiente de realização do direito material". 8

O tempo é um inimigo indelével da efetiva realização do direito material, e, portanto, deve merecer tratamento jurídico específico, sob pena de transformar a prestação jurisdicional em uma atividade inócua e com isso, colocar em xeque a credibilidade do Poder Judiciário e do próprio ordenamento jurídico vigente, perante o meio social por ele regulado. ${ }^{9}$

\section{COGNIÇÃO DAS TUTELAS DE URGÊNCIA}

A análise acerca da teoria da cognição do juiz em planos no processo civil, defendida por Kazuo Watanabe ${ }^{10}$, indica que se pode estudar a cognição em duas direções. Uma diz respeito ao sentido horizontal que determinará a cognição plena ou parcial do objeto, enquanto a segunda cita o sentido vertical voltado à cognição exauriente, sumária e superficial.

\footnotetext{
${ }^{5}$ PINTO, Nelson Luiz. A antecipação da tutela como instrumento de efetividade do processo e de isonomia processual. Revista de Processo. n. 105. São Paulo: Revista dos Tribunais, 2002. p. 46.

${ }^{6}$ SANTOS, Ernane Fidelis dos. Novíssimos perfis do processo civil brasileiro. Belo Horizonte: Del Rey, 1999. p. 19.

${ }^{7}$ PINTO, Nelson Luiz. Op. cit. p. 43-44.

${ }^{8}$ MOREIRA, José Carlos Barbosa. Por um processo socialmente efetivo. Revista de Processo. n. 105. São Paulo: Revista dos Tribunais, 2002. p. 181.

${ }^{9}$ A esse respeito, Cruz e Tucci afirma que "o tempo constitui importantíssimo vetor no plano do direito material" e "são notórios os reflexos do tempo na órbita do processo judicial". Assim, "intolerável duração do processo constitui enorme obstáculo para que ele cumpra, de forma efetiva e tempestiva, os seus compromissos institucionais". "Imprescindível, destarte, que se desfira obstinada luta contra o tempo, que é implacável inimigo do processo", porquanto "é certo que no processo, como vaticinara Couture, o tempo é algo mais do que ouro: é Justiça". (In: TUCCI, José Rogério Cruz e. Tempo e Processo. São Paulo: RT, 1997. p. 141-146.)

${ }^{10}$ WATANABE, Kazuo. Da cognição do processo civil. Campinas: Bookseller, 2000. p. 51.
}

Revista de Teorias da Justiça, da Decisão e da Argumentação Jurídical e-SSN: 2525-9644|Curitiba|v.2 |n. 2 |p.62-81| Jul/Dez. 2016. 
Segundo Kazuo Watanabe "a cognição é prevalentemente um ato de inteligência, consistente em considerar, analisar e valorar as alegações e as provas produzidas pelas partes" 11 e pode inequivocamente ser considerada uma forma de técnica processual tendente à construção de procedimentos ajustados às reais necessidades de tutela.

Na cognição horizontal, os limites são impostos pelos elementos objetivos do processo, como pressupostos processuais, condições da ação e o mérito, podendo ser plena ou parcial, segundo a extensão da apreciação do juiz. No primeiro caso - plena -, todos os elementos objetivos acima citados serão objetos da atividade cognitiva do juiz. Já no segundo caso - parcial -, somente um ou alguns desses elementos objetivos serão apreciados.

Em relação à vertical, classifica-se a cognição quanto à profundidade em exauriente, sumária e rarefeita. No primeiro caso - exauriente -, o juiz firma seu convencimento pautado num juízo de certeza. No segundo - sumária -, esse convencimento é consubstanciado num juízo de probabilidade ou plausibilidade do direito. Por fim, no terceiro- cognição rarefeita -, pouco há de atividade cognitiva do magistrado, eis que sua atividade será, em suma, a execução de um título anteriormente perfectibilizado.

O procedimento de cognição parcial privilegia os valores certeza e celeridade - ao permitir o surgimento de uma sentença com força de coisa julgada material em um tempo inferior àquele que seria necessário ao exame de toda a extensão da situação litigiosa - mas deixa de lado o valor "justiça material". ${ }^{12}$

A cognição sumária limita-se a conhecer o provável ou plausível, porquanto se volta ao juízo de probabilidade e verossimilhança. O plano vertical, direcionado à atividade sumária, classifica-se quanto ao que objetiva: a) assegurar a viabilidade da realização de um direito ${ }^{13}$; b) realizar, em vista de uma situação de perigo, antecipadamente um direito ${ }^{14}$; c) realizar, em razão das peculiaridades de um determinado direito e em vista da demora do procedimento ordinário, antecipadamente um direito ${ }^{15}$; d) realizar antecipadamente um direito ${ }^{16}$, quando este surge como evidente e a defesa é exercida de modo abusivo. ${ }^{17}$ (coloquei os artigos do código atual. Achei melhor também jogar os artigos na nota de rodapé para não poluir a sequencia de raciocínio do texto, já que é informação complementar)

\footnotetext{
${ }^{11}$ Ibidem. p. 41.

${ }_{12}$ MARINONI, Luiz Guilherme. A antecipação da tutela. São Paulo: Malheiros, 2004. p. 32.

${ }^{13}$ Tutela cautelar do art. 301, 305 e ss, do CPC.

${ }^{14}$ Tutela de urgência fundada no art. 300, do CPC.

${ }^{15}$ Liminares de determinados procedimentos especiais, como nas ações possessórias.

${ }^{16}$ Tutela da evidência fundada no art. 311, do CPC.

${ }^{17}$ MARINONI, Luiz Guilherme. Op. cit. p. 34.
}

Revista de Teorias da Justiça, da Decisão e da Argumentação Jurídical e-SSN: 2525-9644|Curitiba|v.2 |n. 2 |p.62-81| Jul/Dez. 2016. 
Ao contrário do que se possa pensar, a sumarização da cognição não depende da cronologia do provimento jurisdicional, mas sim da relação entre os fatos que se busca afirmar e as provas capazes de prová-los. Na tutela sumária, o juiz não declara, mas apenas se reporta à probabilidade do direito existir. Equivale dizer que não haverá óbice algum ao juiz decidir, após cognição exauriente, que aquele direito sumariamente provido não existe ${ }^{18}$.

\section{SATISFATIVIDADE X DEFINITIVIDADE}

A tutela satisfativa pode se direcionar a uma tutela provisória ou definitiva. Essa última somente poderá existir após atividade cognitiva exauriente, pois a tutela definitiva é imutável, apta a perpetuar seus efeitos e a consolidar a situação jurídica objeto de apreciação, mediante a entrega da prestação jurisdicional.

Deve-se ressaltar, segundo Luiz Guilherme Marinoni, que "há no procedimento comum, um enorme conflito entre o direito à cognição definitiva (direito de defesa) e o direito à tempestividade da tutela jurisdicional”19. Assim, para proteção do autor que tem razão e do próprio direito tutelado na ação, a atividade jurisdicional deve ser realizada em concomitância de atos de natureza cognitiva e executiva.

Para tanto, é imprescindível que os institutos processuais postos a serviço da efetividade sejam interpretados de acordo com o espírito que influenciou as reformas do Código de Processo Civil.

A tutela jurisdicional é dividida em satisfativa (reparatória e preventiva) e cautelar. Francisco Cavalcanti Pontes de Miranda ${ }^{20}$ suscita a contraposição existente entre cautelaridade e satisfatividade, indicando a impossibilidade do pedido cautelar ser satisfativo, pois a cautelaridade é contraposta à satisfatividade porque essa é capaz de realizar o direito material. Quando há satisfação do direito não há cautelaridade.

A atividade jurisdicional depara-se com o empecilho do tempo necessário ao desenvolvimento e prática de todos os atos tendentes à efetividade do processo, pois o momento predisposto pelo procedimento para a concessão da tutela na maioria das vezes se distancia substancialmente do momento em que deva ela ser prestada com critérios de justiça.

\footnotetext{
${ }^{18}$ Fato esse que faz surgir inclusive o dever de reparar os prejuízos da parte adversa, na forma do art. 302, do CPC.

${ }^{19}$ MARINONI, Luiz Guilherme. Tutela antecipatória, julgamento antecipado e execução imediata da sentença. São Paulo: RT, 1997. p. 26.

${ }^{20}$ MIRANDA, Francisco Cavalcanti Pontes de. Comentários ao código de processo civil de 1973. Rio de Janeiro: Forense, 1979. p. 74.
} 
Direcionada às situações urgentes, que demandam imediata intervenção judicial, sob pena de se concretizar a inefetividade do provimento final, foi criada a chamada tutela de urgência, que se utiliza dentre outras, de duas técnicas diferenciadas para a sua atuação: a tutela cautelar e a tutela antecipada.

\title{
4 A TUTELA ANTECIPADA
}

A tutela antecipatória, de maneira festejadíssima, nasceu de uma reforma impulsionada pelos valores celeridade, efetividade, mediante cognição sumária. Tutela antecipada segundo Nelson Nery Júnior, “é providência que tem natureza jurídica mandamental, que se efetiva mediante execução lato sensu, com o objetivo de entregar ao autor, total, ou parcialmente, a própria pretensão deduzida em juízo ou os seus efeitos"21.

Dentre todas as alterações legislativas trazidas pelas reformas processuais, ressalta Cândido Rangel Dinamarco que:

\begin{abstract}
A mais genérica e festejada é a do novo art. 273 do Código de Processo Civil, que autoriza o juiz, à base de uma razoável probabilidade do direito do demandante, dar-lhe desde logo uma tutela provisória, da mesma natureza da que poderá ser outorgada a final. Elimina-se a espera pela cognição exauriente e se oferece desde logo ao demandante a fruição do bem ou situação jurídica que veio pleitear através do processo. Com isso, neutralizam-se manobras do demandado visando ao retardamento da tutela (art. 273, II) ou, de todo modo, poupa-se o demandante de prejuízos irreparáveis ou de difícil reparação $(\operatorname{art.} 273, \mathrm{I}){ }^{22}$
\end{abstract}

Assim, a reforma processual de 1994 acabou por conferir nova redação ao artigo 273 do

CPC, e inseriu no sistema vigente a antecipação de tutela através da Lei 8.952/94.

Art. 273. O juiz poderá, a requerimento da parte, antecipar, total ou parcialmente, os efeitos da tutela pretendida no pedido inicial, desde que, existindo prova inequívoca, se convença da verossimilhança da alegação e:

I - haja fundado receio de dano irreparável ou de difícil reparação; ou

II - fique caracterizado o abuso de direito de defesa ou manifesto propósito protelatório do réu.

$\S 1^{\circ} \mathrm{Na}$ decisão que antecipar a tutela, o juiz indicará, de modo claro e preciso, as razões do seu convencimento.

$\S 2^{\circ}$ Não se concederá a antecipação da tutela quando houver perigo de irreversibilidade do provimento antecipado.

$\S 3^{\circ}$ A efetivação da tutela antecipada observará, no que couber e conforme sua natureza, as normas previstas nos arts. 588, 461, $\S \S 4^{\circ}$ e $5^{\circ}$, e $461-\mathrm{A}$.

\footnotetext{
${ }^{21}$ NERY JÚNIOR, Nelson. Código de processo civil comentado. 3. ed. São Paulo: RT, 1997. p. 546.

${ }^{22}$ DINAMARCO, Cândido Rangel. Nasce um novo processo civil. In: TEIXEIRA, Sálvio de Figueiredo (coord.). Reforma do código de processo civil. São Paulo: Saraiva, 1996. p. 10.
} 
$\S 4^{\circ}$ A tutela antecipada poderá ser revogada ou modificada a qualquer tempo, em decisão fundamentada.

$\S 5^{\circ}$ Concedida ou não a antecipação da tutela, prosseguirá o processo até final julgamento.

$\S 6^{\circ}$ A tutela antecipada poderá ser concedida quando um ou mais dos pedidos cumulados, ou parcela deles mostrar-se incontroverso.

$\S 7^{\circ}$ Se o autor, a título de antecipação de tutela, requerer providência de natureza cautelar, poderá o juiz, quando presentes os respectivos pressupostos, deferir a medida cautelar em caráter incidental do processo ajuizado.

O espírito da lei que modificou tal artigo para o fim de inserir a antecipação de tutela fundou-se na ideia de que antecipar efeitos práticos era arma poderosa no sentido de se assegurar a efetividade jurídica do provimento, pois teria o condão de tornar mais próxima possível a situação conferida pela lei e que seria alcançada espontaneamente, pelo simples cumprimento do dispositivo legal.

Ensina José Eduardo Carreira Alvim que:

O processo cautelar, ao longo de mais de duas décadas, produziu excelentes resultados, mostrando-se o instrumento adequado para dar resposta às prestações jurisdicionais de urgência, fora dos estreitos limites do mandado de segurança. Além disso, mostrou-se fecundo de experiências - mormente depois do advento da nova Constituição, com o abuso de leis temporárias, veiculadas por medidas provisórias do Executivo, o que permitiu aos tribunais traçar-lhe perfil mais ou menos definido, inclusive no campo da tutela satisfativa. Foram essas experiências, colhidas na prática diuturna dos tribunais, que permitiram o florescimento das idéias de antecipação da tutela e tutela liminar fora dos lindes estritamente cautelares, afinal consagradas pela recente reforma processual. ${ }^{23}$

Sabe-se que vários países consagram o instituto da antecipação de tutela. Na Europa Ocidental, a tutela antecipada é uma das modalidades da tutela cautelar. ${ }^{24}$ No Brasil, no entanto, em seu período embrionário, a antecipação de tutela chegou a sofrer resistência por parte da doutrina. Ovídio Araújo Baptista da Silva asseverou que:

A introdução em nosso direito de uma forma de tutela antecipatória - tão extensa quanto o permite sua conceituação, como tutela genérica e indeterminada - invalida todos os pressupostos teóricos que sustentam o processo de conhecimento, pois as antecipações de julgamento, idôneas para provocarem tutela antecipatória, pressupõem demandas que contenham, conjugadas e simultâneas, as atividades de conhecimento e execução. $^{25}$

A crítica embasava-se no paradoxo: cognição sumária $\mathrm{x}$ satisfatividade, pois a antecipação da tutela tem o condão de prover de imediato a satisfação pretendida em tutela final, sem exercer a cognição exauriente necessária. No mesmo sentido, a satisfatividade da tutela

\footnotetext{
${ }^{23}$ ALVIM, José Eduardo Carreira. A antecipação de tutela na reforma processual. In: TEIXEIRA, Sálvio de Figueiredo (coord.). Op. cit. p. 55. Grifos no original.

${ }^{24}$ CARNEIRO, Athos Gusmão. Da antecipação da tutela. 5. ed. Rio de Janeiro: Forense, 2004. p. 12-15.

${ }^{25}$ SILVA, Ovídio Araújo Baptista da. Tutela antecipatória e juízos de verossimilhança. In: MARINONI, Luiz Guilherme (coord.). O processo civil contemporâneo. Curitiba: Juruá, 1994. p. 127-128.
} 
cautelar, até então utilizada com finalidade de antecipação de tutela, era igualmente objeto de críticas ferrenhas. Tanto pelo desvirtuamento da natureza acessória/assecuratória da cautelar, quanto pela impossibilidade de "satisfazer-se um direito" mediante tutela cautelar.

A tutela antecipatória exige requisitos mais rígidos à sua concessão, pois uma vez satisfeito total ou parcialmente a pretensão in judice, o retorno ao status quo ante pode tornar-se remoto, além de pretender os próprios efeitos finais do processo, muito além do caráter acessório/instrumental da tutela cautelar.

Tanto por isso, a antecipação de tutela possui as características de revogabilidade e provisoriedade, pois o juiz está legalmente autorizado a revogar ou modificar a tutela concedida a qualquer tempo, segundo o que preceituava o $§ 3^{\circ}$ do art. 273 do Código do Processo Civil, por se tratar de tutela concedida com base em cognição sumária. De outra via, o juiz também pode conceder a antecipação antes negada, desde que, por óbvio, preenchidos os requisitos faltantes.

A profícua polêmica doutrinária direcionou-se a variados aspectos da antecipação de tutela. Como exemplo, cita-se as palavras de Cândido Rangel Dinamarco, para quem:

\begin{abstract}
É preciso receber com cuidado o alvitre de Marinoni, para quem se legitimaria o sacrifício do direito menos provável, em prol da antecipação do exercício "de outro que pareça provável". O direito não tolera sacrifício de direito algum e o máximo que se pode dizer é que algum risco de lesão pode-se legitimamente assumir. $\mathrm{O}$ direito improvável é direito que talvez exista e, se existir, é porque na realidade inexistia aquele que era provável. O monografista fala da coexistência entre o principio da probabilidade e o da proporcionalidade, de modo a permitir-se o sacrifício do bem menos valioso em prol do mais valioso. Mesmo com essa atenuante, não deve o juiz correr riscos significativos e, muito menos, expor o réu aos males da irreversibilidade, expressamente vetados pela lei vigente $\left(\operatorname{art} .273, \S 2^{\circ}\right) .^{26}$
\end{abstract}

Havia dificuldade de conciliação entre o caráter satisfativo da antecipação tutela e a própria reversibilidade exigida para a sua concessão, principalmente ao se denotar que ao mesmo tempo duas condições deveriam persistir: alcance dos efeitos da sentença final e possibilidade de restabelecimento da situação inicial.

Nesse sentido, elucida Cândido Rangel Dinamarco que:

Sendo necessário conciliar o caráter satisfativo da tutela antecipada com o veto a possíveis efeitos irreversíveis da decisão que a concede, cabe ao juiz em cada caso impor as medidas assecuratórias que sejam capazes de resguardar adequadamente a esfera de direitos do réu. ${ }^{27}$

Posteriormente, sedimentou-se entendimento de que o risco de irreversibilidade é inerente à antecipação de tutela e aflige ambas as partes, pois pode derivar tanto da concessão,

\footnotetext{
${ }^{26}$ DINAMARCO, Cândido Rangel. A reforma do código de processo civil. 4. ed. São Paulo: Malheiros, 1997. p. 144. Grifos no original.

${ }^{27}$ DINAMARCO, Cândido Rangel. Op. cit. p. 146.
}

Revista de Teorias da Justiça, da Decisão e da Argumentação Jurídical e-SSN: 2525-9644|Curitiba|v.2 |n. 2|p.62-81| Jul/Dez. 2016. 
como da não concessão da tutela e uma visão extremamente rigorosa do $\S 2^{\circ}$ do art. 273 do CPC poderia resultar em indevido óbice à prática da antecipação.

Assim, após rico embate doutrinário, a matéria pacificou-se e não há maiores discussões acerca da legitimidade de medidas provisórias satisfativas, embora não se possa olvidar que sua concessão esteja sujeita a regime próprio, inconfundível e em alguns aspectos mais rigoroso que o das medidas cautelares. Assim, conclui Nelson Nery Junior, em relação à tutela antecipatória que:

É tutela satisfativa no plano dos fatos, já que realiza o direito, dando ao requerente o bem da vida por ele pretendido com a ação de conhecimento. Com a instituição da tutela antecipatória dos efeitos da sentença de mérito no direito brasileiro, de forma ampla, não há mais razão para que seja utilizado o expediente das impropriamente chamadas 'cautelares satisfativas', que constituiu uma contraditio in terminis, pois as cautelares não satisfazem: se a medida é satisfativa, ipso facto, não é cautelar. É espécie de gênero tutelas diferenciadas. ${ }^{28}$

Diz Joaquim Felipe Spadoni que:

Como a antecipação de tutela lhe permitirá desfrutar imediatamente dos efeitos práticos da decisão definitiva de procedência, é fundamental que o autor demonstre nos autos a verossimilhança de sua alegação, a consistência jurídica de sua argumentação, respaldada por provas que demonstrem, de forma inequívoca, a ocorrência dos fatos constitutivos de seu direito. ${ }^{29}$

Nesse clima de mudanças paradigmáticas, asseverou José Eduardo Arruda Alvim:

Como a concessão do provimento jurisdicional não é mais uma graça do Estado, mas um direito da parte, preparem-se juízes e tribunais para o exercício de sua nobre missão de outorgar tutela na forma da lei, não devendo o termo poderá ser entendido como passaporte para a omissão, deixando para a sentença final o que, segundo a lei, deva ser, de logo, antecipado. ${ }^{30}$

O espírito instituidor da antecipação da tutela volta-se à asseguração do equilíbrio nas relações jurídicas, à igualdade processual, sem que uma das partes sofra conseqüências em razão da má-fé, do tempo, da desproporcionalidade de condições entre os litigantes, firmando-se num supedâneo da maior relevância, de garantia constitucional a um processo justo e efetivo.

\section{A ESTABILIZAÇÃO DA TUTELA ANTECIPADA DE CARÁTER ANTECEDENTE}

\footnotetext{
${ }^{28}$ NERY JÚNIOR, Nelson. Op. cit. p. 546.

${ }^{29}$ SPADONI, Joaquim Felipe. Op. cit. p. 81.

${ }^{30}$ ALVIM, José Eduardo Carreira. A antecipação de tutela na reforma processual. In: TEIXEIRA, Sálvio de Figueiredo (coord.). Op. cit. p. 56.
} 
Como principal novidade relativa ao tema, como dito, apresenta o Código de Processo Civil vigente uma nova roupagem que agora possibilita a Antecipação de Tutela em Caráter Antecedente, com a estabilização de seus efeitos ${ }^{31}$.

\footnotetext{
Art. 304. A tutela antecipada, concedida nos termos do art. 303, torna-se estável se da decisão que a conceder não for interposto o respectivo recurso.

$\S 1^{\circ}$ No caso previsto no caput, o processo será extinto.

$\S 2^{\circ}$ Qualquer das partes poderá demandar a outra com o intuito de rever, reformar ou invalidar a tutela antecipada estabilizada nos termos do caput.

$\S 3^{\circ} \mathrm{A}$ tutela antecipada conservará seus efeitos enquanto não revista, reformada ou invalidada por decisão de mérito proferida na ação de que trata o § 20 .

$\S 4^{\circ}$ Qualquer das partes poderá requerer o desarquivamento dos autos em que foi concedida a medida, para instruir a petição inicial da ação a que se refere o $\S 2$, prevento o juízo em que a tutela antecipada foi concedida.

$\S 5^{\circ} \mathrm{O}$ direito de rever, reformar ou invalidar a tutela antecipada, previsto no $\S 20$ deste artigo, extingue-se após 2 (dois) anos, contados da ciência da decisão que extinguiu o processo, nos termos do $\S 10$.

$\S 6^{\circ}$ A decisão que concede a tutela não fará coisa julgada, mas a estabilidade dos respectivos efeitos só será afastada por decisão que a revir, reformar ou invalidar, proferida em ação ajuizada por uma das partes, nos termos do § 20 deste artigo.
}

O artigo 304 do Código de Processo Civil vigente determina a estabilização dos efeitos da tutela antecipatória antecedente, em caso de ausência de recurso contra decisão que concedêla. Equivale dizer que, ao instruir seu pedido com elementos apenas suficientes à arguição da tutela antecipada, pode a parte deixar de discutir toda a matéria naquele momento, para fazê-lo somente após.

O juiz concederia a tutela antecipada e a parte autora teria 5 (cinco) dias, se o juízo não lhe arbitrar outro prazo, para aditar a petição inicial com a fundamentação agora completa.

Nesse ínterim, caso não haja recurso do réu contra decisão que concedeu a tutela antecipada, seus efeitos seriam estabilizados e qualquer das partes poderia solicitar desarquivamento para revê-la, reformá-la ou invalidá-la, num prazo máximo de 2 (dois) anos, contados da ciência da decisão que extinguiu os autos.

Segundo simples leitura do Código do Processo Civil vigente, essa é a situação da estabilização da tutela antecipada. Ocorre que muitas dúvidas foram levantadas, que exigem maior reflexão e atenção quanto ao que firmará a prática forense.

\section{PONDERAÇÕES NECESSÁRIAS}

\footnotetext{
${ }^{31}$ MEDINA, José Miguel Garcia. Novo Código de Processo Civil Comentado. 4. ed. São Paulo: RT, 2016. p. 483484.
}

Revista de Teorias da Justiça, da Decisão e da Argumentação Jurídical e-SSN: 2525-9644|Curitiba|v.2|n. 2|p.62-81| Jul/Dez. 2016. 
Diante do exposto, propõem-se as seguintes ponderações, desenvolvidas na forma de três raciocínios, como se segue.

6.1 Raciocínio primeiro: a inércia do réu é condição única da estabilização dos efeitos da antecipação de tutela ou há outros requisitos necessários à estabilização?

O artigo 303, caput, da Processual Civil dita que se tornam estáveis os efeitos da tutela antecipada, se da decisão que a conceder não for interposto recurso.

Em primeiro lugar, há de se indagar se esse recurso apto a afastar a estabilização seria somente aquele interposto pelo réu. Ou se mesmo o autor que recorre, afastaria a estabilização. E se os embargos de declaração também afastariam, de per si, a estabilização dos efeitos da antecipação da tutela.

Segundo uma interpretação lógico-teleológica do dispositivo, a finalidade do afastamento da estabilização por intermédio do recurso aconteceria pela natureza de inconformismo com a tutela provida. Ou seja, a intenção é que não se permita estabilizar efeito ainda controverso (ou não consentido) sobre a matéria. Assim, o recurso do autor também afastaria a estabilização, pois a matéria ainda estaria em discussão.

O mesmo não ocorreria com os embargos declaratórios, por não possuir em seu bojo, genuína carga de inconformismo. Assim, não se configura como insurgência inconformada o recurso que pretende tão somente sanar omissão, contradição ou obscuridade de decisão, como os embargos declaratórios, tanto de autor como de réu.

Ultrapassada essa questão inicial, outra dúvida reside na (des)necessidade de inércia no aditamento do autor para estabilização dos efeitos da tutela antecipada. É a chamada tese da dupla inércia. Segundo seus defensores, para estabilizar, além da ausência de recurso do réu, deve haver em concomitância, a ausência de aditamento do autor.

Murilo Teixeira Avelino aduz:

Parte da doutrina defende a chamada dupla inércia. Para haver estabilização seria necessário que tanto o réu não apresentasse Agravo de Instrumento (recurso cabível nos termos do art. 1.015, I [nota mental coletiva: e os Eds?!]) quanto o autor não aditasse a petição inicial. ${ }^{32}$

\footnotetext{
${ }^{32}$ AVELINO, Murilo Teixeira. Que bicho é esse? Tutela provisória Antecipada Antecedente de urgência e a tese da única ou dupla inércia para a estabilização. Disponível em https://ponderandoodireito.wordpress.com/2016/04/21/que-bicho-e-esse-tutela-provisoria-antecedente-antecipadade-urgencia-e-a-tese-da-dupla-ou-unica-inercia-para-a-estabilizacao. Acesso em 1 abr. 2016.
}

Revista de Teorias da Justiça, da Decisão e da Argumentação Jurídical e-SSN: 2525-9644|Curitiba|v.2 |n. 2 |p.62-81| Jul/Dez. 2016. 
Segundo esse entendimento, somente se estabilizaria a tutela antecipada no caso em que o réu não recorre e nem autor adita. Caso um dos dois se manifeste pelos respectivos meios, não haveria condições à estabilização.

Há ainda uma parte da doutrina, em sentido contrário, que entende que para estabilizar, é necessária, além da ausência de recurso, a providência de aditamento do autor. A diversidade de opiniões no assunto demonstra quão abrangente se faz o deslinde da questão.

É o caso de Leonardo Ferres da Silva Ribeiro, para quem não haverá estabilização da tutela antecipada, "mesmo diante da ausência de recurso (ou resistência) do réu, quando o autor não aditar a petição inicial (inc. I do art. 303), o que implicará a extinção do processo (art. 303, $\S 2^{\circ}$ ), com a perda da eficácia da tutela antecipada deferida" ${ }^{, 33}$.

Discorda-se de ambos os posicionamentos. Não há de se exigir dupla inércia e nem mesmo o aditamento do autor, para que a estabilização seja possível.

Primeiro, porque, no referente à tese da dupla inércia, estar-se-ia a configurar uma consequência prática desastrosa à questão, conferindo-se ao réu o conforto de apenas aguardar que o aditamento não fosse realizado, quando ao contrário, deve o réu desincumbir-se da tarefa de demonstrar que o autor não tem razão, para que um direito do qual ele já está gozando lhe fosse retirado. Caso haja interesse no aprofundamento da questão, esse ônus deve ser imputado ao réu, e não ao autor, que cumpriu com suficiência sua parte, a ponto de ver deferida a tutela pretendida.

\begin{abstract}
A ideia é a de que se o autor emendar a petição inicial o processo não será mais extinto, seguindo-se o procedimento regular tendo em vista que agora a cognição pode se dar de forma ampla e verticalmente aprofundada. (...) Concedida a tutela, haverá comunicação de autor e réu a respeito. $\mathrm{O}$ autor, que já tem advogado nos autos será intimado pelo diário oficial; o réu, que ainda nem tem ideia do que está acontecendo, será citado/intimado pessoalmente. Fica bem claro que o prazo para o aditamento da inicial vai começar e acabar (bem) antes do prazo para o recurso. Isso poderia gerar uma situação bizarra caso exigisse a dupla inércia. O réu, comunicado da decisão provisória, podia ficar tranquilo deitado na rede aguardando o final do prazo para o autor aditar a inicial. Caso não houvesse aditamento, o réu continuaria de boa sem precisar fazer nada, já que o processo seria extinto e a tutela cairia. Havendo aditamento, o réu poderia impugnar ou não a decisão provisória, pois a estabilização já estaria impedida face ao próprio aditamento, fazendo com que o procedimento se desenrolasse regularmente. Quaisquer destas hipóteses dá ao réu um superpoder no processo: excluir para sempre o caput do art. 304! Se o autor não adita, perde; se ele adita não há estabilização. Sendo bem direto: não haveria nunca estabilização, seja lá o que seja isso! Não ia servir pra nada todo o estardalhaço de dizer diversas e diversas vezes que você deseja se submeter ao procedimento dos artigos 303 e $304 .^{34}$
\end{abstract}

\footnotetext{
${ }^{33}$ RIBEIRO, Leonardo Ferres da Silva. Tutela Provisória: Tutela de urgência e tutela de evidência do CPC1973 ao CPC2015. São Paulo: RT, 2015. p. 221.

${ }^{34}$ AVELINO, Murilo Teixeira. Op. cit.
}

Revista de Teorias da Justiça, da Decisão e da Argumentação Jurídical e-SSN: 2525-9644|Curitiba|v.2 |n. 2 |p.62-81| Jul/Dez. 2016. 
Ao depois, porque, em relação à segunda posição, que exige o aditamento para a estabilização, um dos objetivos da estabilização de tutela antecipada antecedente é justamente a realização de um direito urgente sem a necessidade de cognição exauriente, estabilizando seus efeitos, caso não haja insurgência contrária do réu.

Se o réu não contraponha a decisão, não será necessário contribuir ao abarrotamento de processos no Poder Judiciário, já que a situação de urgência foi sanada, e o aditamento faria caminhar os autos para cognição exauriente, sem que o réu tenha "movido uma palha" para isso, sem que tenha demonstrado esse desejo. É dizer, não se fez necessária à efetividade processual o aprofundado exame e sequer haveria, nesse caso, interesse do autor em modificar a situação, que lhe é favorável, caso não pretenda discutir aprofundadamente a matéria.

O CPC/2015 optou por esse caminho, ao dispor que, caso o réu não impugne a liminar concedida ao autor (nos termos do caput do art. 304), a apresentação do pedido "principal" por este será desnecessária, mas qualquer das partes poderá fazê-lo (cf. §2 do art. 304 do CPC/2015): o réu, com o intuito de rever, reformar ou invalidar a decisão; o autor, eventualmente, com o intuito de "confirmar" a decisão que concedeu a tutela antecipada e obter pronunciamento que faça coisa julgada material. Tendo em vista a ultratividade da decisão que concede a tutela satisfativa autônoma, parece correto supor que, com mais frequiência, tal iniciativa acabará sendo tomada pelo réu, e não pelo autor. $^{35}$

Não obstante o art. $303, \S 2^{\circ}$, determine o aditamento da inicial, sob pena de extinção sem resolução de mérito, tal exigência não vem determinada no dispositivo legal que trata da estabilização da tutela, o que faz concluir que a necessidade de aditamento refere-se tão somente ao encaminhamento da ação, quando necessário, ao seu trâmite normal. Assim, seria uma interpretação extensiva e ilógica, adicionar-se uma condição à estabilização, à uma situação que era favorável ao autor em um primeiro momento e, sem qualquer ato do réu passa a lhe ser desfavorável.

Alias, segundo a própria interpretação literal do dispositivo próprio da estabilização, seria suficiente para afastar a estabilização a mera interposição recursal, pois não há qualquer exigência legal, como visto, que se reporte ao comportamento do autor da demanda, para fim de estabilização da tutela antecipada.

O artigo 304 não traz, como requisito à estabilização, após concedida a antecipação de tutela, qualquer ulterior ato do autor, pois "a estabilização em nada se relaciona com o

\footnotetext{
${ }^{35}$ MEDINA, José Miguel Garcia. Op. cit. p. 517-518.
} 
aditamento ou não da inicial, mas sim com a inércia do réu em recorrer, conforme pode ser apreendido da leitura do caput do art. 304, que impõe ao réu recorrer!” ${ }^{36}$.

Além disso, e mais importante, deve-se ressaltar que o aditamento refere-se à completude da matéria debatida e não ao preenchimento de requisitos da antecipada. A inicial será sumária pelos objetos apresentados à cognição e não pela superficialidade do conjunto probatório ao pedido de urgência. Vale dizer, o autor deixa de demonstrar na inicial toda a demanda que pretende discutir, o que não quer dizer que não deva demonstrar satisfatoriamente o preenchimento dos requisitos para a concessão da tutela antecipada, referente ao pedido nela suscitado.

$\mathrm{Na}$ antecipação, embora o mérito principal não seja examinado, o mérito da própria antecipação continua sendo a plausibilidade e deve ser preenchido! Caso o juiz entenda que os requisitos da antecipada não estão suficientemente demonstrados, pode e deve determinar a emenda da inicial, sob pena de extinção dos autos, aqui sim por culpa do próprio autor, conforme inteligência do $\S 6^{\circ}$, do mesmo artigo.

6.2 Segundo raciocínio: definição da inércia do réu, as várias situações envolvendo o recurso da decisão e a constestação como demonstração do inconformismo

Inicialmente, é necessário definir o que o legislador pretendeu ao determinar que o recurso afastaria a estabilização, pois, como visto, para afastar a estabilização, basta que o réu se insurja contra a decisão, através de interposição recursal.

Situação que se impõe, portanto, é o exame desse recurso.

A exigência legal é a "mera interposição recursal", pois a letra da lei determina que a antecipação de tutela "torna-se estável se da decisão que a conceder não for interposto o respectivo recurso" 37 .

Embora o Enunciado 27 da EFAM, use o termo "admitido o recurso interposto na forma do art. 304 do $\mathrm{CPC} / 2015^{, 38}$, há de se advertir que a admissão recursal, a que se refere o enunciado, diz respeito à conversão do rito antecedente em principal para apreciação definitiva do mérito da causa, e não à estabilização dos efeitos da antecipada, como se poderia pensar.

\footnotetext{
${ }^{36}$ AVELINO, Murilo Teixeira. Op. cit.

${ }^{37} \mathrm{CPC}$, art. 304.

38 Enunciado 27 da Escola de Formação e Aperfeiçoamento de Magistrados: "Admitido o recurso interposto na forma do art. 304 do CPC/2015, converte-se o rito antecedente em principal para apreciação definitiva do mérito da causa, independentemente do provimento ou não do referido recurso".
}

Revista de Teorias da Justiça, da Decisão e da Argumentação Jurídical e-SSN: 2525-9644|Curitiba|v.2 |n. 2|p.62-81| Jul/Dez. 2016. 
Assim, embora não pareça coerente, ainda que o recurso traga uma "receita de pamonha em seu conteúdo", seria já suficiente a afastar a estabilização, pois cumpriria o requisito legalmente exigido para esse fim. Interpretação diversa a esse respeito implicaria novamente em se atribuir outra condição, desta vez ao réu, que o próprio legislador não atribuiu, o que não se pode admitir.

Outro ponto a se questionar é se outra manifestação de inconformismo do réu, sem a providência recursal, poderia afastar a estabilização, caso ocorra, antes do recurso uma resposta inconformada do réu, como contestação ou reconvenção.

Frise-se: pela letra da lei, não basta que o réu conteste a demanda. Se não houver recurso da decisão que antecipou a tutela, esta se tornará estável e o processo, com ou sem contestação, será extinto. Essa forma de interpretação a nosso ver, não pode prevalecer. Em verdade, qualquer forma de oposição (v.g., contestação, reconvenção) deve ter o condão de evitar a extinção do processo. Basta a resistência, a manifestação do inconformismo do réu, a qual, pode se dar não só pelo recurso. É bem verdade que na maioria dos casos o prazo para apresentação de defesa terá início somente após a realização da audiência, de forma que primeiro se escoará o prazo para o recurso de agravo. De qualquer forma, citado o réu ele poderá, se quiser, adiantar a contestação. A vingar uma interpretação literal antevê-se um risco potencial de aumento dos agravos de instrumento nessa situação, pois a parte seria obrigada a lançar mão do recurso se quiser que a ação prossiga e seja julgado o pedido final. ${ }^{39}$

Seguindo essa linha de entendimento, Marinoni afirma:

Se o réu não interpuser o agravo de instrumento, mas desde logo oferecer contestação no mesmo prazo - ou ainda manifestar-se dentro desse mesmo prazo pela realização da audiência de conciliação ou mediação, tem-se que entender que a manifestação do réu no primeiro grau de jurisdição serve tanto quanto a interposição do recurso para evitar a estabilização dos efeitos da tutela. Essa solução tem a vantagem de economizar o recurso de agravo e de emprestar a devida relevância à manifestação de vontade constante da contestação ou do intento de comparecimento à audiência. Em ambas as manifestações, a vontade do réu é inequívoca no sentido de exaurir o debate com o prosseguimento do processo. ${ }^{40}$

Considerada, dessarte, a natureza de inconformismo das respostas à inicial (contestação e reconvenção), estaria qualquer delas apta a afastar a estabilização. O legislador nada determinou, mas seria uma interpretação lógica e não realizada em seu desfavor; ao contrário, uma vez denotado o inconformismo do réu, por resposta à inicial ou recurso, afastada estaria a estabilização.

6.3 Raciocínio derradeiro: a definitividade da decisão estabilizada após o prazo de dois anos

\footnotetext{
${ }^{39}$ RIBEIRO. Leonardo Ferres da Silva. Op. cit. p. 221.

${ }^{40}$ MARINONI, Luiz Guilherme; ARENHART, Sérgio Cruz; e MITIDIERO, Daniel. Novo Código de Processo Civil comentado. 2. ed. São Paulo: RT, 2016. p. 387.
}

Revista de Teorias da Justiça, da Decisão e da Argumentação Jurídical e-SSN: 2525-9644|Curitiba|v.2 |n. 2 |p.62-81| Jul/Dez. 2016. 
Segundo art. 304, $\S 2^{\circ}$, ambas as partes podem propor ação tendente a rever, reformar ou invalidar a decisão de estabilização da tutela antecipada. Acrescenta o $\S 5^{\circ}$, que o prazo para se rever, reformar ou invalidar a decisão será de 2 (dois) anos, a contar da ciência da decisão que extinguiu o processo.

Luiz Guilherme Marinoni acrescenta que "não se pode falar em coisa julgada material no âmbito do processo cautelar e do processo sumário, porque a cognição sumária, peculiar a estes processos, não permite carga declaratória suficiente à produção de coisa julgada material" $" 41$.

A antecipação de tutela fará coisa julgada somente no caso de ter sido determinada em sede de sentença, conforme exigência de atividade cognitiva exauriente.

A iniciativa de se pleitear pronunciamento fundado em cognição exauriente sobre a lide pode ser tomada por qualquer das partes, isto é, tanto o autor da ação em que foi concedida a tutela satisfativa autônoma, quanto o réu.

Assim, com a estabilização, a decisão formada segundo cognição sumária poderia ser enfrentada num prazo de dois anos. Ocorre que nessa antecipação da tutela, o juiz não perfaz seu convencimento segundo um juízo de certeza, próprio à cognição exauriente, pois o magistrado não pretende atribuir definitividade àquela decisão, mas segundo um juízo de probabilidade. A concessão da tutela antecipada implica apenas juízo de cognição sumária, dimensionada segundo o binômio "a) pelo menor grau de imunidade de que se reveste a medida antecipatória em relação à definitiva e b) pelas repercussões que ela terá na vida e patrimônio dos litigantes"42.

A decisão proveniente de tutela antecipada não tem o condão de levar à coisa julgada material, exatamente porque não existe declaração de um direito, mas tão somente antecipação dos efeitos do provimento final. Mas após os 2 anos, ainda seria possível rediscutir a matéria, diante de sua definitividade?

\begin{abstract}
A resposta que se impõe é positiva. O prazo de dois anos encerra a possibilidade de se ajuizar uma ação que reabra a discussão do processo extinto, nos exatos limites e contornos da lide originária na qual se deferiu a antecipação de tutela. Passado esse prazo, diante da inexistência de coisa julgada acerca da matéria, nada impede que qualquer das partes, respeitados os prazos prescricionais pertinentes, ingresse com uma nova demanda, com cognição exauriente, que diga respeito ao mesmo bem da vida discutido na ação que foi extinta. ${ }^{43}$
\end{abstract}

\footnotetext{
${ }^{41}$ MARINONI, Luiz Guilherme. Tutela cautelar e tutela antecipatória. São Paulo: RT, 1994. p. 141.

${ }^{42}$ DINAMARCO. Cândido Rangel. Op. cit. p. 144.

${ }^{43}$ WAMBIER, Tereza Arruda Alvim; CONCEIÇÃO, Mara Lúcia Lins; RIBEIRO, Leonardo Ferres da Silva; MELlO, Rogério Licastro Torres de. Primeiros Comentários ao Código de Processo Civil. 2. ed. São Paulo: RT, 2016. p. 567.
} 
Com efeito,

a decisão que concede a tutela antecipada, caso não impugnada nos termos do caput do art. 304 do CPC/2015, torna-se estável e produz efeitos fora do processo em que foi proferida, efeitos estes que perduram, se não alterada a decisão que lhes serve de base. Trata-se da ultratividade da tutela. Há, aí, situação peculiar: a decisão não precisa ser "confirmada" por decisão fundada em cognição exauriente (como a sentença que julga o pedido, após a antecipação dos efeitos da tutela). Trata-se de pronunciamento provisório, mas, a despeito disso, dotado de estabilidade, que não se confunde com coisa julgada. Com outras palavras, o pronunciamento é provisório e estável: provisório, porque qualquer das partes pode ajuizar ação com o intuito de obter um pronunciamento judicial fundado em cognição exauriente, e estável, porque produz efeitos sem limite temporal [...]. Face a sumariedade da cognição realizada, tal pronunciamento não faz coisa julgada. 44

Assim, a partir dos dois anos, embora definitiva, e, ainda aqui, sem realizar coisa julgada material, a decisão poderia ser rediscutida, mas em novos autos, por ter realizado apenas coisa julgada formal. Significa dizer que a coisa julgada a que se refere a vedação do $\S 6^{\circ}$ do art. 304 é a material e não a formal.

A opção pela ausência de coisa julgada material é herança jurídica do sistema francês e italiano, onde passado o prazo, nada impede que quaisquer das partes ingresse com nova demanda, com cognição exauriente, relativa ao mesmo objeto já discutido ${ }^{45}$.

Afirmam Giovanni Arieta, Francesco de Santis e Luigi Montesano que "sono le parti, com Il loro comportamento concludente, a determinare il tempo dell'uteriore produzione degli effetti dela misura cautelare"46. Isto é, são as partes que determinam o tempo de duração da medida porque podem, embora a definitividade após os dois anos, reapreciar a matéria em novos autos.

\section{CONSIDERAÇÕES FINAIS}

A novità vem garantir maior efetividade ao direito material, conferindo a agilidade inerente ao pedido urgente, bem como afastar a alta incidência de propositura de processos de cognição exauriente, diante da inércia do requerido.

Não se limita, assim, a tutela jurisdicional apenas ao pronunciamento judicial dado em favor do titular do direito subjetivo, mas à viabilização dos meios necessários à realização e gozo do direito em questão, o que exige que tal pronunciamento seja dotado de efetividade.

\footnotetext{
${ }^{44}$ MEDINA, José Miguel Garcia. Op. cit. p. 517.

45 “Art. 669-octies do CPC Italiano, 'Il provimento del giudizio di mérito è puramente facoltativo ed è rimesso all'iniziativa dell'uma o dell'altra parte"”. (In: COMOGLIO, Luigi Paolo et al., Lezioni ..., vol. II, p. 44. Apud: Idem.)

${ }^{46}$ Idem.
}

Revista de Teorias da Justiça, da Decisão e da Argumentação Jurídical e-SSN: 2525-9644|Curitiba|v.2 |n. 2 |p.62-81| Jul/Dez. 2016. 
Certo é que, ao se estar diante de uma novidade processual, muitos aprofundamentos ainda serão imprescindíveis à perfeita compreensão da intenção do legislador e de seus deslindes práticos.

Toda a polêmica que envolve o tema já vem sendo discutida por gabaritada doutrina e será ainda aperfeiçoada com a prática forense, caberá, contudo, ao meio acadêmico o acompanhar desses processos favorecendo os debates e apontamentos pertinentes.

\section{REFERÊNCIAS BIBLIOGRÁFICAS}

AVELINO, Murilo Teixeira. Que bicho é esse? Tutela provisória Antecipada Antecedente de urgência e a tese da única ou dupla inércia para a estabilização. Disponível em https://ponderandoodireito.wordpress.com/2016/04/21/que-bicho-e-esse-tutela-provisoriaantecedente-antecipada-de-urgencia-e-a-tese-da-dupla-ou-unica-inercia-para-a-estabilizacao. Acesso em 1 abr. 2016.

BAUR, Fritz. Tutela jurídica mediante medidas cautelares. São Paulo: Fabris, 1985.

CARNEIRO, Athos Gusmão. Da antecipação da tutela. 5. ed. Rio de Janeiro: Forense, 2004. Código de Processo Civil: anteprojeto/Comissão de Juristas Responsável pela Elaboração de Anteprojeto de Código de Processo Civil. Brasília: Senado Federal, Presidência, 2010.

DINAMARCO, Cândido Rangel. A reforma do código de processo civil. 4. ed. São Paulo: Malheiros, 1997.

MARINONI, Luiz Guilherme (coord.). O processo civil contemporâneo. Curitiba: Juruá, 1994. . A antecipação da tutela. São Paulo: Malheiros, 2004.

Tutela antecipatória, julgamento antecipado e execução imediata da sentença.

São Paulo: RT, 1997.

. Tutela cautelar e tutela antecipatória. São Paulo: RT, 1994.

MARINONI, Luiz Guilherme; ARENHART, Sérgio Cruz; e MITIDIERO, Daniel. Novo Código de Processo Civil comentado. 2. ed. São Paulo: RT, 2016.

MEDINA, José Miguel Garcia. Novo Código de Processo Civil Comentado. 4. ed. São Paulo: RT, 2016.

MIRANDA, Francisco Cavalcanti Pontes de. Comentários ao código de processo civil de 1973. Rio de Janeiro: Forense, 1979.

MOREIRA, José Carlos Barbosa. Por um processo socialmente efetivo. Revista de Processo. n. 105. São Paulo: Revista dos Tribunais, 2002. 
NERY JÚNIOR, Nelson. Código de processo civil comentado. 3. ed. São Paulo: RT, 1997.

PINTO, Nelson Luiz. A antecipação da tutela como instrumento de efetividade do processo e de isonomia processual. Revista de Processo. n. 105. São Paulo: Revista dos Tribunais, 2002.

RIBEIRO, Leonardo Ferres da Silva. Tutela Provisória: Tutela de urgência e tutela de evidência do CPC1973 ao CPC2015. São Paulo: RT, 2015.

SANTOS, Ernane Fidelis dos. Novíssimos perfis do processo civil brasileiro. Belo Horizonte: Del Rey, 1999.

SPADONI, Joaquim Felipe. Fungibilidade das tutelas de urgência. Revista de processo. n. 110. São Paulo: Revista dos Tribunais, 2003. v. 28.

TEIXEIRA, Sálvio de Figueiredo (coord.). Reforma do código de processo civil. São Paulo: Saraiva, 1996.

TUCCI, José Rogério Cruz e. Tempo e Processo. São Paulo: RT, 1997.

WAMBIER, Tereza Arruda Alvim; CONCEIÇÃO, Mara Lúcia Lins; RIBEIRO, Leonardo Ferres da Silva; MELLO, Rogério Licastro Torres de. Primeiros Comentários ao Código de Processo Civil. 2. ed. São Paulo: RT, 2016.

WAMBIER, Tereza Arruda Alvim; DANTAS, Bruno; TALAMINI, Eduardo; DIDIER, Fredie. Breves Comentários ao Código de Processo Civil. 2. ed. São Paulo: RT, 2016.

WATANABE, Kazuo. Da cognição do processo civil. Campinas: Bookseller, 2000. 